\title{
KIKUYU SYSTEM OF LAND TENURE
}

THERE have been so many varied expressions of opinion on the subject of Kikuyu land tenure that it cannot but be of advantage to examine such evidence as is available, with a view to making an attempt to arrive at some definite conclusions. Nor should this investigation be postponed any longer; to so great an extent are these people being daily affected by the European incursus into their midst. In a few years' time it will be quite impossible to obtain satisfactory evidence, and the very fact that there are even now differences of opinion tends to prove that no more time should be lost.

The field of my own personal inquiries was what is now known as the Kikuryu district; and there is indisput:able evidence that the A-kikuyu emigrated from the slopes of Mt. Kenia to this locality at a date which can hardly be put back more than 100 years ago. I shall refer to this evidence later on; it will be necessary first to describe the system of land tenure as found in the Kikuyu district to-day and to compare it with that found in the other localities inhabited by A-kikuyu; especially in those regions whence the A-kikuyu of the Kikuyu district are known to have emigrated. Whenever we find the customs identical we can at any rate assume it to be a fact that the emigrants brought them with them, and it will become immediately obvious that they were in vogue before they came into their present country. And when we find the customs identical, in these instances at any rate, we shall have gone far to establishing their genuineness.

It will be convenient to discuss the evidence under the following two headings:-

A. Acquisition of land (original method of)

B. Present Tenure and inheritance.

The Kikuyu district was in 191 I divided up into six 


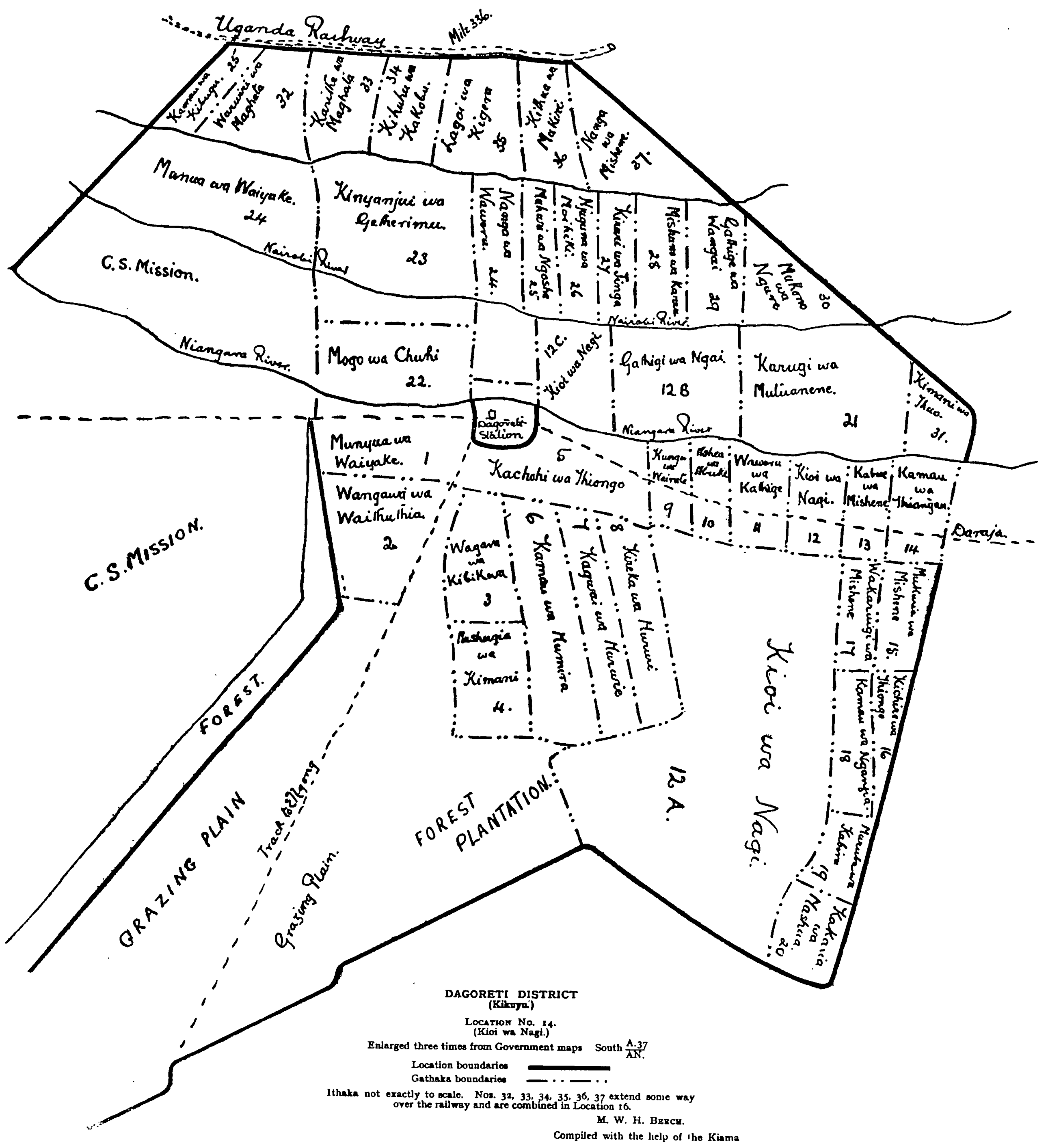


locations, comprising in all some 42,400 acres, and having a population of 3,909 men, $6,83^{2}$ women and 10,283 children. My investigations were made in each location separately, and several thousands of witnesses were individually or collectively examined.

\section{A. Original Method of Acquisition of Land.}

The result of my inquiries on this point was an unanimous agreement that all arable land was originally purchased by the A-kikuyu from the Dorobo forest hunters whom they found in possession on their arrival. ${ }^{1}$ Purchases were made by individuals, and holdings held by individuals. On the arrival of the A-kikuyu the land purchased by them was all dense forest. The hunting tribes having no use for the open plains did not assert ownership. Consequently as regards the plains, which are now the grazing grounds, there are no traditions of these having been purchased, nor does anyone assert individual rights. They are regarded as communally held by the tribe. All forest land is potentially arable land; consequently the same law applies to each, and with the exception of timber rights, which will be dealt with below, forest land will for the purposes of this paper be henceforth included in arable land.

The 6 locations in the Kikuyu district will here for the sake of convenience be referred to as $(a)(b)(c)(d)(e)(f)$.

Location (a) was found to be, with the exception of what is now European farms, divided up into 37 holdings covering an area of about 17,000 acres. About half of the whole area was stated to have been originally purchased from a Dorobo named Malindi by a Mu-kikuyu named Gitu for " 500 oxen, sheep and goats." The statement was confirmed by all the

\footnotetext{
1 I have no evidence as to how the Dorobo obtained the land. The origin of these people is still somewhat wrapped in mystery, but It is to be presumed that they followed the custom of previous tribes which they displaced, e.g., the "Athi" of Nyeri. Wherever found, the A-Kikuyu claim to have bought the land from "hunter tribes."

In the Kikuyu district, the emigration being so recent, it would naturally be Dorobo that they found there.

The payments were originally made doubtless as a "price of peace." The Arabs obtained their land from the Galla in the same way.
} 
elders present, including Thiongo wa Gitu, the son of the vendee, and Suagi, the son of the vendor.

There was universal agreement as to the boundaries of location (b) the next examined, of which a sketch-map is appended to this paper. This again consisted of about 5,000 acres divided up into 37 holdings all of which were derived from three Dorobo individuals. Two of these, Malimbi and Muthugini, were brothers, the sons of one Baribari, from whom they inherited the land and sold it to the present owners. Malimbi had in 1912 a son, Suagi, mentioned in connection with location (a), and Muthugini a son Thindi, still living in the location. Having disposed of all their inheritances they are themselves landless. The fact that they do not dispute the sales is therefore important. The rest of the location was originally owned by a Dorobo named Beira who adopted a Mu-kikuyu named Waiyake, ${ }^{2}$ who, on the former's death, inherited a large tract of land, Waiyake leaving a son Munua, who is still living, and who, as will be seen by the map, is still an owner.

Plot No. I cost 150 sheep and goats and is about 30 acres in area. This evidence was obtained from such persons named as are still living.

Location (c) consisted of two small patches amounting to about 5,000 acres, in the middle of what is now the Government Forest Reserve, and was divided into 17 holdings. The Government representative of the location, one Wamaitito wa Thanenga, was the son of the original Dorobo owner. He with another Dorobo, Wananga wa Kithimati were living on part of their original inheritances, and their statement tallied exactly with those of their Wa-kikuyu neighbours.

Location (d) (about 3,000 acres) was divided up into 26 holdings. One Goibita, the son of an original Dorobo owner named Gathaga, himself an old man with a large family, was the only surviving witness on the Dorobo side to the original purchase of the land by Wa-kikuyu.

Location (e) (about 4,000 acres) was interesting as it consisted of new forest land to which the Wa-kikuyu had

\footnotetext{
2 Here is an isolated instance of land having been acquired as a result of adoption. I know of no other, but, at any rate, the custom involved bere is a Dorobo, not a Kikugu, one.
} 
emigrated not more than 15 years ago. Such as are here live side by side with the Dorobo with whom they have to a large extent intermarried. The holdings were apparently bought here as hunting areas and cultivation is quite recent.

The location is situated in the forest at the summit of the Kikuyu escarpment overlooking the Kedong valley, and was divided into 30 holdings.

Location $(f)$ was a very large one of some 9,000 acres. Nearly three-quarters of the whole is owned by one $\operatorname{man}^{1}$ Gatonyo wa Munene, a very old man whose father, Munene, bought the holding for 1,000 oxen, sheep and goats from three Dorobo named Marishoga, Rurete and Ithiri, the last named of whom had three sisters, Gutibe, Rothoi and Tubio. None of these are living, nor were any of their descendants available. It is unnecessary for my purpose, and it would be wearisome to the reader to treat this subject in any further detail. The point on which stress should be laid is that during the whole examination none of the many witnesses disagreed as to a single essential point.

Such then is the system in vogue at the present day which has existed in the Kikuyu district for, in most cases, certainly 100 years.

Did they evolve this system on the spot, or did they bring it with them?

It will be advantageous to examine evidence obtained from the district from which, and near which, they originally migrated, and any other that may throw light on the subject.

\section{Evidence from Kiambu district.}

The Kiambu district adjoins the Kikuyu and the inhabitants are emigrants in exactly the same way. The following statement is that of the Provincial Commissioner, Mr. F. IV.

1 Gatonyo is over 80 years of age and was born in the location.

The fact that it was his father who bought the land is useful as a guide in fixing the approximate date of the Kikuyu emigration to these parts, as is the appeared ages of the various descendants of the original Dorobo owners. The date of emigration by these means can be fixed with approximate correctness at 100 years ago.

- The fact that a few Kikuyu now claim land near the Magai which they could not have held before the advent of the Pax Britannica does not affect the general argument. 
Isaac, and is taken from appendix Vol. II. East African Law Reports :-

"In Kiambu the original inhabitants of the Kikuyu Reserve were the Dorobo. Their method of obtaining a claim on land was as follows :

"Game pits were dug and the man who first trapped an animal took possession of the ridge ${ }^{1}$ and all the game pits on it to the exclusion of all others. Land was obtained (i.e. by the A-kikuyu)

"(I) by purchase;

"(2) as payment of dowry for a daughter given in marriage, in which case the Dorobo became absorbed in the tribe.

"(3) As payment for blood-money."

Mr. G. S. A. Northcote, the District Commissioner of Kiambu, gives me the following information in a private letter :-

"My informants tell me that in the memory of man, land has always been held by individual tenure with the exception that grazing rights are common to all. Now, as you know, individual tenure appears when land becomes very closely occupied. Moreover, we know the Kikuyu (i.e. the A-kikuyu of Kiambu) migrated from the east side of Mt. Kenia.

"Probably at one time where the tribe was much smaller, it was confined within certain boundaries as were the Kisii by the Lumbwa, Masai, and Kavirondo, and individual tenure took the place of communal. ${ }^{8}$ Then the tribe swelling still more, burst its bounds and migration began, the immigrants carrying with them the only idea of land tenure which they knew and which they may have practised for centuries. There is another explanation of individual land tenure which arises from the description of the method by which the present 'Gethaka'" were establshed. The Dorobo from whom the Kikuyu purchased the right to

- The Kikugu country is a succession of ridges and valleys.

In the latter there runs, or used to run, a stream. The holdings generally run from the middle of the top of a ridge to the middle of the stream, or by watercourse at the bottom.

- There is, however, as far as I know, no evidence to suppart this conjecture.

- Gethaka, pl. ithaka, is a Kikuyu word having the definite meaning of an individual holding. The existence of this word in the Kikugu rocabulary is strong evidence of the antiquity of the custam. 
fell trees and cultivate, and the right to live at peace had from time immemorial partitioned out the forest into hunting areas. No Dorobo might hunt in another area without leave; nor could he hang his honey boxes elsewhere than in his own forest.

"When the Kikuyu came, the emigrant father of the family purchased the aforesaid rights over a portion of such an area : The Ndorobos' boundaries were well known and consisted of streams where possible and otherwise of trees. These boundaries were adopted by the Kikuyu. Naturally as he cleared the forest the game went further in, and the piece of forest between the recesses of the forest and the part sold became game-less and valueless to the Dorobo owner and he would be more willing to sell that bit-and so the process went on.

"Possibly both these explanations are right. I know as surely as one can know in such matters that the Kikuyu acquired their present 'Gethaka' from the Dorobo by this latter method, but I suspect that had the land always been held communally prior to the migration all the newly acquired lands would have reverted to communal tenure, and I guess that individual tenure was known to the Kikuyu long ago-at any rate it can safely be said that none of the land on this (the West) side of the Tanu held by the Kikuyu was ever under Kikuyu communal tenure, and no individual tenure arose either at the time of migration or previously. Of course since we drove back the Masai, the Kikuyu claim some 'Gethaka' which cannot have been theirs 1 . . . (regarding the Kenia A-kikuyu). Every answer I have had from the Kikuyu of Kiambu tallied with those given me in previous questionings farther North."

\section{From Embu district.}

To pass to the slopes of Kiambu whence the A-kikuyu of whom we have been speaking emigrated to Kikuyu and

\footnotetext{
- A noticeable instance of this occurred in the Kikuyu district, where a Government chief claimed that large area of land, stretching from the Niangara River to the N. En-gong Hills, was ceded to him by Masai in return for services rendered to them, when they were engaged in a disastrous civil war. A good deal of evidence was brought forward in support of this claim, but there was nothing to sbow that the particular section of Masai, who were alleged to have disposed of the land, had any righte over it at all.
} 
Kiambu. Embu is on the S.E. slopes of Mt. Kenia and the following is extracted from a communication from Mr. R. G. Stone, the district commissioner of that district :-

"So far as the cultivated portions are concerned I am convinced that such is not the case (i.e. that the land is held communally) and that the land is owned individually, though for how long that has been so, and whether it was originally held by the community or not, I am not prepared to express an opinion.

"By cultivated land I mean such parts of the district that are, or have been used for crops in distinction to those areas which are communally used for grazing areas. Practically all the arable land is claimed by the heads of individual families who each own their own distinct share, and so a whole ridge is generally owned by a clan which is composed of these families. The prisent generation do not seem to have any knowledge of a system other that that of individual tenure. ... With regard to cattle grazing areas, I think it can properly be said that they are held by, and for the use of, the community, and that they are used as common pasture lands. At any rate that seems to be the custom here, and I very much doubt if individuals can lay claim to distinct and separate possession of grazing ground.

From the Nyeri district.

"The Nyeri district bounded by the Uaso Nyiro river is the most northerly habitat of the A-kikuyu, and the following quotations are from communication by Mr. H. R. McClure, the District Commissioner of that locality. He says "Re land tenure: (I) In the first place it appears that there can be no doubt that the whole system is arranged on a basis of individual tenure. (2) It seems equally certain that every portion of the arable land of the district, whether in cultivation or lying fallow, is owned by somebody. (3) The origin of the ownership of the land is obscure and mythical in character. The most popular story is to the effect that the land was originally owned by a tribe of hunters known as the 'Athi,' each of whom appears to have had hunting rights over a certain district. By arrangement these districts were ceded to 
the incoming A-kikuyu and were cultivated by them and became their property. These districts and small holdings are known by the name of 'Kithaka,' and have been handed down from father to son until the present day. There is a very strict entail on these properties which cannot be cut except in the case of father disinheriting his heir."

\section{From the Fort Hall district.}

The Fort Hall district occupies a portion midway between the Embu and the Kikuyu districts.

Mr. R. Weeks the District Commissioner having but recently arrived at his post sent me the following communication of Mr. L. Lawford, his predecessor in charge. He writes :-

"In the first place I believe myself to be correct in saying that land among the A-kikuyu is individually owned and not communally, in that it is stated that in years long past the Kikuyu country then being forest and in the tenure of the Wanderobo, the A-kikuyu gradually travelled down from the North and East in small bands and bought land from the Wanderobo and cut it and cultivated it. By this means from a small beginning, the nation, gradually clearing land, grew to its present dimensions and the land to its present cultivated state, so that every man had bought or bartered for his own land which has been handed down from father to son ever since, families undoubtedly moving forward to pastures new and leaving a relation in charge of the old land."

From the Chuka and Mwimbe.

The Chuka and Mwimbe are to be found adjoining to, and are closely related to, the Wa-kikuyu. Of them Mr. St. T. Orde-Browne, the Assistant District Commissioner in charge writes :-

"The general principle (i.e. of land tenure) is undoubtedly individual ownership in a most definite form : no sort of socialism exists, nor, on the other hand, is there anything like a Feudal system. This individual ownership is derived in theory from the original purchase of the land from the predecessors of the present tribes, who, again, owned the 
land : consequently every sort of land in all parts, belongs in theory to someone. This system admits of renting, and also of selling. ..."

Subsidiary Evidence of Forest Laws.

Before summarising the results of this evidence it may not be out of place to give a brief description of Forest Laws as I found them in the Kikuyu district.

It appears that there is practically no forest in the district which is not in the Government Forest Reserve.

There are definite owners of the "Ithaka" of all the land in Forest Reserve and elsewhere, and their names and localities are known to all the councils.

It transpires that the owner of the "Gethaka" in each locality was the owner of the trees upon it: that there was, however, no difference in the price of forest land and grazing land : that when land was sold the trees upon it went with the land.

Timber, however, was never sold, it was always given free. It was the custom for anyone wishing to cut wood to ask the owner of the "Gethaka " first, but as a matter of fact anyone from any locality could cut any trees for domestic purposes in anyone's "Gethaka" without any penalty being imposed.

No one however, could clear any forest for the purpose of cultivation without the permission of the owner, and apparently also of the Eiders.

Forest land for cultivation was either given or sold by the owner, but timber could always be cut with impunity.

Nowadays the rights over the few trees that remain in the reserve are jealously guarded by their proprietors.

The elders were unanimous in their statement that definite owners could be produced.

It is evident, however, that actual timber or trees were not considered as property, i.e. as having any value to the owner.

Summary of evidence.

We can summarise as follows :-

The locality of Mt. Kenia is where we find the A-kikuyu first. This is where they apparently finally settled at the 
close of the Bantu immigration. Recent immigrations were further South to Fort Hall. Thence later still to Kiambu and Kikuyu where they were brought to an abrupt standstill by the Masai.

The ages of the descendants of the original Dorobo vendors enable us to place the emigration into Kikuyu at roughly 100 years ago.

These incomers obtained their land by individual purchase from the hunter tribes whom they found in occupation.

That exactly the same method is described by the Kenia A-kikuyu proves conclusively that the immigrants brought their system with them.

There is no evidence whatever to support communal tenure, either in practice or in tradition. As regards the grazing lands, the evidence is rather to the effect that tenure is non-individual rather than that it is communal : it is negative not positive.

The correct answer is probably that the A-kikuyu had no rights, communal or individual, over the plains, but the custom of using them by all and any has led to their being spoken of when questioned only, as being communal property of the tribe.

\section{B. Existing System of Tenure and Inheritance.}

Having discussed the acquisition of land and the original method of tenure, it remains to examine the existing system and the laws of inheritance.

As the system obtaining in the Kikuyu district where I was stationed will be found to be discussed by Messrs. Isaac, Northcote and Dundas, I do not propose to add more than an occasional footnote to the observations of the various administrative officers quoted, before proceeding to examine the results.

\section{In Kiambu district.}

Regarding the Kiambu district the Hon. C. Dundas, District Commissioner, is quoted in Vol. IV. East African Law Reports as follows :-

"All land belongs to the original purchaser and, on his 
death, to the whole family. The senior members are only the nominal holders. ${ }^{1}$ No land can be sold without consent of at least all the senior owners. Marriage relationship gives a right to cultivate but not of ownership. Cultivation gives no right to ownership of land and the tenant may be turned off at any time."

The Provisional Commissioner, Mr. F. W. Isaac is again quoted as follows :-

"On the death of an Ithaka owner the land is not actually divided but remains the possession of the male descendants of the deceased.

"No female can inherit or own land."

"The eldest son apportions to each member of the family an area for cultivation etc., which gives the right of occupation but not of sale.

"Any member of the family has the right to cultivate and protect from fire any indigenous tree on the Ithaka, and by so doing becomes the owner of the tree.

"No part of an Ithaka can be sold until the consent of the older members of the family has been given. The family jointly has a right to lease land to any member of the tribe.

"A nativè who desires to rent land approaches a family with a fat-tailed sheep. This is killed and eaten and the applicant is then shewn where he can cultivate. Originally rent was not always insisted upon; when paid it consisted of two pots of beer per annum ${ }^{3}$ which was consumed by the family on a stated day-latterly the rent has been compounded for a payment of Rs.2 which is taken by the eldest son. Sheep and goats cannot be accepted as rent because they are the recognised currency which constitutes a purchase of land, and

\footnotetext{
1 The eldest wn or, if there is none, the eldest brother becomes the nominal owner. Actually, however, the whole family retain their share, at any rate as regards (a) right of cultivation, (b) a cay in the matter of disposal or otherwise.

- But there are elaborate rules as to moman's life interest in lands, just as certain duties with regard to cultivation are her privileges, and hers alone.

- In many cases I found that this rent of beer, though usually admitted as being a due, was not invariably paid. The tessee could be called upon for the beer when required by the women, but the fact of his not having paid in cases where it was not demanded did not invalidate his title to cultivate. Direct refusal to pay, however, rendered the occupant liable to ejection.
} 
if accepted would create a cloud on the title. The usual method of making the Ithaka boundaries, is by planting the ordinary Kikuyu lily at certain points. As to whether the cultivator has an absolute right to demand land for cultivation is controvertible. I am however informed that originally he had this right, or at any rate, the power of refusal if it ever existed was never exercised.

"When it became known that a cultivator had entered into negotiations with a Dorobo to purchase an Ithaka he was immediately expelled and all his crops cut down.

"When a cultivator ceases planting all leasehold rights lapse. All trees planted by a cultivator are his own property, and if he abandons his cultivation, he still maintains his right to the trees.

"The cultivator has a right to graze sheep and goats on the Ithaka rent free :This enters frequently in marriage customs."

Mr. G. S. Northcote, District Commisioner, writes to me as follows :-

"The answer (as to whether rent is paid) is a negative with a qualification. No rent is paid: in fact the principle is recognised and the system avoided: they say that if any property changed hands the children of the rent payer would in time to come claim part of the land from the children of the Gethaka owner, saying that their father had paid for the land. It must be remembered that the only currency was stock, and when land was bought was paid for in stock: it can be easily understood how the fear of a fraudulent claim would deter the Kikuyu from taking rent.

But although rent is not taken there is a semi-feudal recognition of the Gethaka owner. If the terant makes 'tembo' 1 he must send a pot to the Gethaka owner : if he kills a sheep he must send a joint. There is no obligation to serve in peace and war as in true feudalism."

\section{In Fort Hall district.}

Mr. R. Weeks, District Commissioner, writes to me from Fort Hall :-

'Tembo, of beer of both kinds, one made of sugar-cane and the other from sweet potatoes. 
"A landowner frequently allows an outsider to cultivate on his land, but as far as I can ascertain there is no fixed period of time or rent. The owner generally accepts a present as a preliminary and then later a portion of the crops reaped, such portion being agreed on at the time of reaping and not in advance. The owner may turn out the lessee at any time, but the latter is entitled to gather any crop then standing."

Mr. Lawford's views on the same district are as follows:-

"No land amongst the A-kikuyu can ever be more than leased, insomuch that a man can lease a portion of land, but on return of the lease money he can immediately and at any time claim back the land again, or his heirs for generations afterwards, the standing crop going to the lessee, he not to cultivate any more.

"The land appears to be one of the few things in A-kikuyu customs in which the women have any part or parcel of inheritance in the form of a cultivated shamba. ${ }^{1}$

"Should a man and his wife wish to break new ground they must do so within the boundaries of their father's portion with the parents' consent. Should the younger generation want to cultivate further afield they can go to another country and lease land, but the owner can at any time redeem it and the tenants must return to their own boundaries or seek to redeem land leased by their family.

"The only exceptions to this appear to be :

"(I) The cursing of a member of a family by means of the assembly of the elders and relations, the public proclamation of the outcasting of the man from the clan and the throwing of an arrow behind the back to signify that the man is expelled from the community; and he can no longer inherit any property of his parents, nor can they claim any share in any wealth he may acquire afterwards.

"(2) It has been stated that the payment of land as bloodmoney could not be redeemed, but there seems to be a variety of opinion on this, and I think that the balance is in favour of the redemption where possible.

"(3) Also the theft of stock from a parent by a son is liable

1 But it must be remembered that it is a life interest only, and therefore not strictly an inheritance. 
to disinherit him, i.e. if a man wishes to buy a wife and goes to his father's herds to raise the necessary funds to pay, without the father's permission, his chance of inheritance is very small. Otherwise the law stands that :

"(a) A man with 3 wives, dying, leaving each wife with one son :-each son on marriage is presented and entitled to a part of his mother's shamba, and $(b)$ on his mother's death the son's wife becomes a complete owner of her mother-inlaw's land, to pass in like manner to her descendants."

"(c) Should the wife be widowed she keeps the shamba and becomes the wife of the deceased husband's nearest male relative : the land going to the sons of the deceased, if left, ${ }^{2}$ and should she bear by the second husband, her sons by him would inherit the land which she would have been given on her second marriage.

"(d) Should a woman be barren, a son by another wife would be told to assist her in the cultivating of the land, and at her death the land would go to him who assisted her.

" $(e)$ The unallotted, uncultivated portions of the land are divided as a family arrangement between the sons.

" $(f)$ Should a man and his wife die leaving a small son or sons, and property in the shape of land, the boy will go to live with his uncles or nearest relation until he grows up and then he is entitled to the landed property left by his father."

1 I.e., to her male descendants. She cannot inherit the land, but she can be the medium of Inheritance. It is the 800 who really inherits the shambs which belonged to his father's wife and in which she had a life interest.

The same life interest passes to the son's wife, but it would be hardly correct to call her a complete owner.

I.e., in reality the nearest male relative inherits the shamba with the wife.

When this wife has male issue, however, it is the son who inherits his mother and with her the shamba, although the nearest male relative does so as guardian if the child is minor, but only until it is of age.

MERVyN H. BEECH.

(To be continued.) 